\title{
Myšlenkové experimenty ve filozofii: Gettierovy př́klady
}

\section{Thought Experiments in Philosophy: Gettier's Examples}

\author{
Marek Picha
}

\section{Úvod}

Dejme tomu, že se vás v pravé poledne někdo zeptá, zda nevíte, kolik je hodin. „Vím,“ odpovíte, ,je přece poledne.“ V takovém případě skutečně víte, kolik je hodin; stačilo mít pravdu, přesněji stačilo mít v poledne přesvědčení, že je poledne. Představme si ale, že odpovíte jinak: „Nezlobte se, ale nevím. Nejspíš poledne." V tomto př́ípadě sice máte opět pravdivé přesvědčení vždyt je opravdu poledne -, ale na vědění to nějak nestačí.

Co vám ve druhém případě chybělo $\mathrm{k}$ tomu, abyste své pravdivé přesvědčení prohlásili za vědění? Již více než dvě tisíciletí se filozofové domnívají, že tím chybějícím prvkem je zdưvodnění. Domnívají se, že o vědění nerozhoduje hlasitost, $\mathrm{s}$ jakou názor šíríte, oddanost, s níž v přesvědčení věříte, ani sebejistota, se kterou stanovisko hájíte. Podstatné jsou důvody, které pro své pravdivé přesvědčení máte. ${ }^{2}$

Epistemologové se ze všeho nejvíc bojí štastné náhody. Pravdivé přesvědčení lze totiž získat docela jednoduše: stačí mít hodně názorů a hodně trpělivosti, jelikož dřive či později se některý z těchto názorů ukáže jako pravdivý. To však neznamená, tvrdí filozofové, že bychom v takových štastných případech měli hned hovořit o vědění. Pravdu můžete mít náhodou, vědění nikoli.

1 Myšlenkové experimenty jsou atraktivní téma pro zpracování v audiovizuální formě. Pěkný základní výklad ke Gettierovým prŕkladům najdete na Crash Course Philosophy (https:// youtu.be/kXhJ3hHK9hQ).

2 První explicitní popis role důvodů v poznávání najdeme v Platónových dialozích Menón a Theaitétos. 
Vědění je navíc hodnotnější než pouhá pravdivá domněnka, nebot vědění spíše povede $\mathrm{k}$ dalšímu budoucímu poznávacímu úspěchu. Když v poledne víte, kolik je hodin, protože jste se podívali na své hodinky, pak budete nejspíš vědět přesný čas i o půlnoci.

Slova vědět, znát, mít věděni, mít vědomost, mít znalost sice používáme zástupně, ale jak jsme viděli v úvodní ilustraci, používáme je ve dvou významech. Jednou volně jako mít pravdivé přesvědčení bez ohledu na to, kdy a jak jsme toto přesvědčení získali, napřr. vím, že poloměr Země je $6378 \mathrm{~km}$, aniž bych tušil, kde jsem to slyšel; podruhé striktně jako mít zdưvodněné pravdivé přesvědčení, např. vím, že můj prsteníček je delší než ukazováček, protože jsem si právě prohlédl svoji ruku. Vědění ve druhém, striktním významu je tradičním tématem filozofie téměř od samotného jejího zrodu. Po většinu té doby se epistemologové domnívali, že předmět jejich zkoumání je jasný a dobře vymezený: nechajíli stranou ono volné používání slova vědět, je znalost plně definována jako zdůvodněné pravdivé přesvědčení. Kdykoli má tedy někdo znalost, má zdůvodněné pravdivé přesvědčení; kdykoli má někdo zdůvodněné pravdivé přesvědčení, má znalost. Epistemologové proto věnovali pozornost jiným, dílčím a praktičtějším otázkám. Ptali se, jaké zdůvodnění je nejlepší, proč lidé věří smyslům, proč lidé věří nesmyslům, co je vlastně ta pravda a jak se k ní dobrat. V roce 1963 však americký filozof Edmund Gettier pomocí skromných příkladů otřásl základy epistemologie a upozornil na kolektivní slepotu filozofů.

V následujícím textu představím Gettierovy příklady a ožrejmím jejich kritický cíl, s pomocí dvou variací poté zdůrazním obecnou strukturu myšlenkových experimentů daného typu. Nakonec popísu některé snahy o odstranění ničivých důsledků těchto př́kladů: obhajobu klasické definice znalosti a rozšíření či doplnění této definice.

\section{Expozice: Gettierovy př́klady}

Gettierův krátký článek Is Justified True Belief Knowledge? obsahuje dva myšlenkové experimenty míŕící stejným směrem. ${ }^{3} \mathrm{~V}$ obou příkladech je zkonstruována scéna, v níž má aktér zdůvodněné pravdivé přesvědčení, nemá však znalost. První z experimentů ocituji, druhý budu poté jen sumarizovat.

3 GETTIER, Edmund L. Is Justified True Belief Knowledge? Analysis. 1963, 23(6), s. 121-123. 
Předpokládejme, že Smith a Jones se ucházejí o jisté pracovní místo. Předpokládejme také, že Smith má silný důvod být přesvědčen o následující konjunkci:

(d) Jones získá onu práci a Jones má v kapse 10 mincí.

Smithovým důvodem pro (d) může být třeba ředitelovo ujištění, že místo nakonec získá Jones, a také, že před deseti minutami sám Smith přepočítal mince v Jonesově kapse. Z propozice (d) vyplývá:

(e) Ten, kdo získá onu práci, má v kapse deset mincí.

Předpokládejme, že Smith si je vědom, že (e) vyplývá z (d), a přijímá (e) na základě silně zdůvodněného $(\mathrm{d})$. $\mathrm{V}$ takovém případě je Smith zdůvodněně přesvědčen o pravdivosti (e).

Dále si však představme, že ačkoli o tom ted' neví, práci dostane sám Smith. A Smith rovněž neví, že on sám má v kapse deset mincí. ${ }^{4}$

Ústřední roli hraje v příkladu přesvědčení, že „práci získá osoba s deseti mincemi“. Jaké jsou důležité vlastnosti tohoto přesvědčení? Zaprvé, v okamžiku, kdy ho aktér přijal, bylo pravdivé, nebot se později ukázalo, že práci skutečně získala osoba s deseti mincemi. Zadruhé, aktér přijal toto přesvědčení proto, nebot šlo o korektní logický důsledek jeho dalšího, důvody podpořeného přesvědčení „práci získá Jones, který má deset mincí“.

Stejný postup nalezneme i ve druhém Gettierově př́kladu, kde je aktér přesvědčen, že „platí tvrzení x nebo tvrzení y“. Toto přesvědčení je pravdivé, nebot platí tvrzení x. Zároveň vzniklo klíčové přesvědčení „platí tvrzení x nebo tvrzení y“ korektním logickým odvozením z jiného, důvody podpořeného nepravdivého přesvědčení „platí tvrzení y“.

Proč je důležité, že v obou případech vzniklo klíčové přesvědčení odvozením z jiného přesvědčení? Korektní logické odvození totiž takzvaně přenáší zdưvodnění. Znamená to jen tolik, že je-li nějaké přesvědčení zdůvodněné (např. když se díky kvalitní mapě domníváme, že „Brno je menší než Praha“) - a my z něj korektně odvodíme jiné přesvědčení $Q$ (např. tudíž „Praha je větší než Brno“") - pak je toto naše přesvědčení $Q$ rovněž zdůvodněné. $V$ obou Gettierových př́ikladech je klíčové přesvědčení zdůvodněné právě díky tomu, že došlo k přenosu zdůvodnění z jiného přesvědčení.

4 Překlad podle PICHA, Marek - PICHOVÁ, Dagmar. 100 myšlenkových experimentů ve filozofii. Olomouc: Nakladatelství Olomouc 2013. 
Smyslem obou scénářů tak je zpochybnění dostatečnosti definice znalosti jakožto zdůvodněného pravdivého přesvědčení. V Gettierových příkladech nesouhlasí výsledek úvahy $\mathrm{s}$ tím, jak znalost běžně připisujeme: soudíme, že aktér má pravdivé přesvědčení $\mathrm{P}$, které je zdůvodněné odvozením z jiného přesvědčení, zároveň se ale zdráháme tvrdit, že tento aktér v dané situaci ví $\mathrm{P}$.

\section{Variace}

Gettierovy př́íklady nepopisují situace, jež by byly výjimečné, či dokonce jedinečné. Poměrně brzy se tedy objevila celá řada barvitých scénářủ na totéž téma; ${ }^{5}$ zmíním zde dva, které vynikají názorností. První gettierovská variace zjednodušuje proces zdůvodnění klíčového přesvědčení:

Představte si, že na louce vidíte nedaleko keře postávat zvíře, které vypadá jako ovce. Na základě této vizuální zkušenosti získáte přesvědčení „na louce je ovce“, ve skutečnosti však vidíte chundelatého bílého psa. Shodou okolností je však v blízkém keři na louce skryta skutečná ovce. Vaše přesvědčení, že na louce je ovce, je tak pravdivé i zdůvodněné. ${ }^{6}$

Místo složitějšího logického odvozování počítá tato variace s přesvědčením založeným na smyslovém vnímání. Odhaluje nám tak nejen základní myšlenku a všudypřítomnost gettierovských příkladů, ale ř́íá nám i něco o tom, jak se k těmto scénářům nestavět: ukazuje, že nemá smysl chtít po aktérech gettierovských situací neobvyklý poznávací výkon. Dejme tomu, že bychom v prŕḱladu s mincemi v kapse vytýkali panu Smithovi, že neměl důvěřovat slovu ředitele. Tvrdili bychom, že ředitelovo svědectví o budoucích událostech je prachmizerným zdůvodněním, které nestačí pro připsání znalosti. Variace s ovcí však ukazuje, že ke gettierovskému případu dojde i tehdy, splníme-li všechny obvyklé nároky na sílu zdůvodnění. Z hlediska síly zdůvodnění se vidění zdánlivé ovce neliší od vidění skutečné ovce.

Z této gettierovské variace je tedy patrné, že kdybychom chtěli problematické příklady řešit posílením nároků na zdůvodnění, museli bychom se stejně zachovat i u př́kladů neproblematických. Pokud by vidění bílého chundelatého zvířete nestačilo jako důvod pro přesvědčení „vidím ovci“ v př́ípadě, že přede mnou stojí pes, pak by to nemělo stačit ani v př́ípadě, že by přede

5 Například SKYRMS, Brian. The Explication of "X Knows that p". Journal of Philosophy. 1964, 64(12), s. 373-89.

6 Jde o parafrázi př́íkladu z CHISHOLM, Roderick M.: Theory of Knowledge. Englewood Cliffs: Prentice Hall ${ }^{3} 1989$, s. 66. Poprvé tato kniha vyšla v roce 1966. 
mnou stála skutečná ovce. Jinak řečeno, nelze požadovat silnější zdůvodňování jen v gettierovských situacích; v okamžiku zdůvodňování totiž nikdy nevíme, zda jsme v gettierovské situaci či nikoli.

Zároveň se ukazuje odolnost gettierovských příkladů vůči zvýšeným nárokům na zdůvodnění. Co kdybychom totiž panu Smithovi přece jen vytkli, že je př́liš důvěřivý a že kdykoli dojde na svědectví o budoucnosti, měl by být stejně jako my všichni obezřetnějšíi? Zvýšili bychom tím obecné požadavky na dobré důvody, nikoli jen požadavky v gettierovských situacích. Na příkladu s ovcí je však dobře patrné, že ani takové obecné zvýšení požadavků by problém neřešilo: vždy lze totiž gettierovský př́klad upravit tak, aby splňoval silnější nároky, a přitom stále vedl k podivným důsledkům. Předpokládejme, že bychom skutečně měli být trochu epistemologicky opatrnější a přistupovat ke skutečnému zdůvodnění přesvědčení „na louce je ovce“ pečlivěji. Neměli bychom se spoléhat jen na povrchní pozorování zvířete z dálky, měli bychom jít blíž, prohlédnout si ho z více stran a poslouchat zvuky, které vydává. I za těchto podmínek by ovšem mohlo dojít ke gettierovské situaci, stačí místo psa umístit na louku o něco propracovanější ozvučenou loutku. Takto lze pokračovat: každé posílení nároku na zdůvodnění by jen vedlo k rafinovanějšímu způsobu, jak ho v gettierovských situacích splnit. Časem by se do hry nejspíše dostali roboti, pak umělé organizmy a nakonec i virtuální realita, ale ke každým silnějším nárokům lze nalézt způsob, jak je obelstít.

Druhá variace je pozoruhodná tím, že se objevila dřive než samotný Gettierův text. Britský filozof Bertrand Russell v knize Human Knowledge: Its Scope and Limits z roku 1948 napsal:

Mějme muže, který se podívá na hodiny, které nejdou, přestože si myslí, že jdou, a který se na ně podívá v okamžiku, kdy zrovna ukazují správný čas; tento muž získá pravdivé přesvědčení o přesném čase, avšak nelze říci, že by měl znalost. ${ }^{7}$

Russell mínil př́ílad se zastavenými hodinkami jako ilustraci špatného zdůvodňovacího postupu. Nešlo mu o zpochybnění definice znalosti, nýbrž o zdůraznění rozdílu mezi pravdivou domněnkou a znalostí. Všimněme si ale, že Russelova ilustrace splňuje navíc i podmínky gettierovských př́ípadů: přesvědčení ,je právě tolik a tolik hodin“ je pravdivé a aktér se ho domnívá na základě dobrého důvodu, tedy pohledu na zařízení, které jindy ukazuje

7 Překlad podle RUSSELL, Bertrand. Human Knowledge: Its Scope and Limits. London: Routledge 2009, s. 140. 
přesný čas spolehlivě, a kterému by proto bylo nerozumné nevěřit. Přesto bychom neřekli, že aktér ví, kolik je právě hodin.

Při zpětném pohledu nalézáme formulace gettierovských problémů v textech ještě starších. ${ }^{8}$ Koneckonců i Russell ve svém př́íkladu patrně vychází z krátké, avšak nesmírně nápadité povídky Lewise Carolla. ${ }^{9}$ Najít gettierovský př́iklad totiž není obtížné, když už víme, co přesně hledáme; potřebujeme $\mathrm{k}$ tomu jen dodržet jednoduchou strukturu:

1. (nepravda) $\mathrm{P}$ je zdůvodněné nepravdivé přesvědčení.

2. (odvození) Přesvědčení Q je zdůvodněné odvozením z P.

3. (náhoda) Q se ukáže jako pravdivé.

Uvedené gettierovské př́klady tak můžeme rekonstruovat následovně:

1. (nepravda) Práci dostane Jones, který má v kapse deset mincí.

2. (odvození) Tudíž práci dostane muž, který má v kapse deset mincí.

3. (náhoda) Práci dostane Smith, který má v kapse deset mincí.

1. (nepravda) Vidím ovci na louce.

2. (odvození) Tudíž na louce je ovce.

3. (náhoda) Na louce za keřem je schovaná ovce.

1. (nepravda) Tyto hodiny ukazují přesný čas.

2. (odvození) Tudíž je právě tolik, kolik tyto hodiny ukazují.

3. (náhoda) Je právě tolik, kolik tyto hodiny ukazují.

\section{Reakce}

Není složité zkonstruovat gettierovské příklady, složité je se s gettierovskými př́klady vypořádat. Největším překvapením daných příkladů totiž není jejich jednoduchost či všudypřítomnost, nýbrž fakt, že něco tak zjevně chybného nelze napravit snadno.

8 Př́klady náhodně pravdivých zdůvodněných přesvědčení lze nalézt např. ve spise Logica od Petra z Mantovy (1492) či v Laghupramanyapariksa indického filozofa Dharmottary (kolem 770).

9 CARrolL, Lewis. The Two Clocks. Poems, Puzzles, and Stories of Lewis Carroll (Lit2Go Edition). 1898. [On-line, cit. 1. 4. 2021.] Dostupné z <https://etc.usf.edu/lit2go/112/poems-puzzles-and-stories-of-lewis-carroll/4953/the-two-clocks/>. 
Gettierovy příklady ukazují potíže tradičního vymezení znalosti. Reakce na tyto potíže lze rozdělit do dvou skupin: první skupina se snaží obhájit tradiční vymezení posílením podmínky zdůvodnění, druhá skupina doplňuje k tradičnímu vymezení další podmínku.

\section{Posílení}

Co když gettierovské př́íklady neodhalují slabinu tradiční definice znalosti, nýbrž jen slabinu našeho každodenního zdůvodňování? Co když jsme se dostali k podivným důsledkům prostě proto, že jsme nepatřičně snížili kritéria? Již jsem zmínil odolnost gettierovských př́kladů vưči zvyšování zdůvodňovacích nároků: př́klady lze upravovat tak, abychom rostoucí požadavky plnili. Existuje však určitá hranice, za kterou už gettierovské př́́klady přizpůsobit nelze.

Všechny gettierovské př́klady totiž vycházejí z předpokladu, že lze mít zdůvodněné nepravdivé přesvědčení, tj. že dobré důvody nejsou zaručeným vodítkem k pravdivým přesvědčením a že zdůvodnění je principiálně omylné. Pan Smith se chová racionálně, když věří nepravdivému slovu ředitele; zvíráata identifikujeme na základě toho, jak vypadají, byt’ se někdy můžeme zmýlit; je dobré věřit hodinkám, přestože jdou čas od času špatně. Tento tzv. falibilistický princip ale nebyl ve filozofii odjakživa, vznikl vlastně až jako odpověd' na striktní chápání vztahu zdůvodnění a pravdivosti. ${ }^{10}$

Jak vypadá striktní pojetí zdůvodnění? Tvrdí, že většina důvodů je jen zdánlivých a že jen velmi málo důvodů zdůvodňuje skutečně. Podle striktního pojetí je totiž zdůvodňování něco jako procházení správné cesty k pravdě: není možné říct, že jsme sice urazili správnou cestu k cíli, ale k cíli jsme se nedostali. Správná cesta nás prostě vždy musí dovést k cíli, protože jinak by to nebyla správná cesta. Stejně tak zdůvodnění nás musí vždy dovést k pravdivému přesvědčení, jinak by to nebylo skutečné zdůvodnění.

Při striktním pojetí zdůvodnění nepředstavují gettierovské příklady žádný epistemologický problém. Přesvědčení „práci dostane Jones, který má v kapse deset mincí“ není skutečně zdůvodněné, a to jednoduše proto, nebot je nepravdivé. A jestliže aktér hned zpočátku postavil své přesvědčení na zdánlivých

10 Prominentní kritiku falibilistického principu lze nalézt v DESCARTES, René. Meditace o pruni filosofii. Praha: OIKOYMENH 2010 (poprvé publikováno 1641), s novější verzí se lze setkat třeba v DRETSKE, Fred I. Knowledge and the Flow of Information, Cambridge: MIT Press 1981. 
důvodech, není divu, že na konci nemá znalost. Tradiční definice znalosti tedy není ohrožena, jen si prostě nesmíme myslet, že každé předkládání rozumně znějících důvodů je hned skutečným zdůvodňováním.

Striktní pojetí tedy řešilo gettierovské příklady ještě dříve, než Gettierovy př́klady vůbec existovaly. Lze však namítat, že jsme za takové řešení zaplatili př́liš vysokou cenu. Pokud totiž spojíme zdo̊vodnění s pravdivostí tak těsně, jak to žádá striktní pojetí, nemůžeme téměř žádné naše přesvědčení označit za zdůvodněné. Naprostou většinu přesvědčení totiž přijímáme na základě důvodů, jež spíše, nikoli ale vždy, vedou k pravdě. Spoléháme na vidění, které nás někdy klame; na úsudek, jenž není vždy správný; na občas selhávající pamět. Pokud bychom všechny tyto postupy označili pouze za zdánlivé, nikoli skutečné zdůvodnění našich pravdivých domněnek, rozsah našich znalostí by se drasticky zmenšil. Striktní pojetí zdůvodnění by znamenalo, že bychom nevěděli téměř nic (což se dá vydržet), hlavně by ale znamenalo, že mluvčí jazyka celou dobu používají výrazy „znalost“ a „vědět“ špatně (což je pro epistemology neobhajitelná představa).

Rovněž lze namítat, že striktní pojetí zdůvodnění sice řeší Gettierovy př́íklady, neřeší však problém, na který tyto příklady upozorňují. Dejme tomu, že bychom si opravdu vyhradili termín „znalost“ jen pro skutečně zdůvodněné pravdivé přesvědčení. Všechna naše pravdivá přesvědčení by tedy patřila bud' mezi skutečné znalosti, nebo mezi pouhé pravdivé domněnky. Jenže i tak bychom uvnitř skupiny pravdivých domněnek stále potřebovali rozlišovat mezi těmi, jež jsou výsledkem náhody, a těmi, jež pocházejí z důvěryhodnějších zdrojů. Stále by nás např́íklad zajímalo, zda se řidič našeho taxi vyhne překážce jen díky štastné souhře okolností, nebo díky tomu, že překážku vidí. Stále bychom potřebovali rozlišovat mezi nezdůvodněným pravdivým přesvědčením a zdánlivě zdůvodněným pravdivým přesvědčením.

Gettierovské prríklady by i za takových okolností upozorňovaly na vážný problém, jen bychom museli některé formulace drobně rozšíriti. Místo zdůvodněného nepravdivého přesvědčení bychom $\mathrm{v}$ prvním kroku uvažovali zdánlivě zdůvodněné nepravdivé přesvědčení; místo odvozeného zdůvodnění ve druhém kroku bychom uvažovali odvození zdánlivého zdůvodnění. Na konci příkladu bychom se pak prostě ptali, proč se naše hodnocení zdánlivě zdůvodněného pravdivého přesvědčení „na louce je ovce“ liší od hodnocení jiného zdánlivě zdůvodněného pravdivého přesvědčení, např. „na louce je keř“. Změnilo by se jen to, že by gettierovské př́íklady neproblematizovaly tradiční pojetí znalosti, nýbrž tradiční pojetí zdánlivého zdůvodnění. 


\section{Doplnění}

Druhá skupina reakcí bere podivné výsledky gettierovských příkladů vážně. Problémem těchto příkladů, shodují se epistemologové, je přiliš mnoho náhody: pan Smith dostane práci souhrou okolností, náhodou je na louce skutečná ovce a měli jsme štěstí, že jsme se podívali na rozbité hodiny ve správný čas. K patřičnému vymezení znalosti musíme nalézt způsob, jak náhodu z poznání vyloučit. Tradiční vymezení znalosti nelze ve stávající podobě zachránit, nebot spojení důvodů, pravdy a přesvědčení tvoří sice nutnou, nikoli však dostatečnou podmínku. Tradiční vymezení je třeba rozšířit.

\section{Bez nepravdivých předpokladů}

Téměř okamžitě se po zveřejnění Gettierova textu objevila reakce, podle níž je problémem daných příkladů usuzování z nepravdivých předpokladů. ${ }^{11}$ Aktér ve všech scénářích dosáhl pravdivého přesvědčení náhodou, navzdory svým nepravdivým východiskům: Smith nesprávně předpokládal, že práci získá Jones; zaměnili jsme psa za ovci; věřili jsme, že hodiny správně fungují.

Podle této reakce je epistemologické zdo̊vodňování vlastně něco jako argumentování. Při zdůvodňování vycházíme z předpokladů, jež podporují naše přesvědčení, při argumentování předkládáme premisy, jež podporují náš závěr. $\mathrm{V}$ obou případech jde o náležité ukotvení důsledků v důvodech. Jak bychom hodnotili argument, který vychází z nepravdivých premis? Bez ohledu na to, zda by takový argument podporoval pravdivý či nepravdivý závěr, bez ohledu na to, jak silně by závěr ze zvolených premis vyplýval, byl by takový argument prostě špatný. Závěr opřený o nepravdivé premisy nelze považovat za obhájený. Se zdůvodňováním je to stejné: ani tam nelze považovat přesvědčení za obhájené, vycházíme-li při jeho zdůvodňování z nepravdy. Tradiční vymezení znalosti je proto nezbytné rozšírít o čtvrtou podmínku, která anuluje zdůvodnění v případě, že je založeno na nepravdivých předpokladech.

Nedostatkem tohoto lákavého řešení je opět skutečnost, že přestože řeší Gettierovy př́klady, neřeší gettierovské problémy. Př́klady lze totiž upravit tak, aby splňovaly dodatečnou podmínku, avšak stále vedly k podivnému výsledku. Pro ilustraci se vrátím k příkladu s ovcí, tentokrát však budu hned

11 CLARK, Michael. Knowledge and Grounds. A Comment on Mr. Gettier's Paper. Analysis. 1963, 24(2), s. 46-48. 
zkraje přemýšlet trochu komplikovaněji. Nejprve na základě vidění chundelatého bílého zvířete na louce získám pravdivé přesvědčení (i) „vidím chundelaté bílé zvíře na louce“ (tedy nikoli nepravdivé přesvědčení „vidím ovci“!). V dalším kroku na základě přesvědčení (ii) „vidím-li na louce chundelaté bílé zviŕre, je to dobrý důvod domnívat se, že na louce je ovce“ odvodím přesvědčení (iii) „mám dobrý důvod se domnívat, že na louce je ovce“. Dále se budu řídit racionálním pravidlem, že (iv) „mám-li dobrý důvod se něco domnívat, domnívám se to“, a tudíž se na základě výše řečeného budu skutečně domnívat, že „na louce je ovce“. Ostatní okolností příkladu jsou zachovány, tj. ve skutečnosti vidím psa, ale za keřem je skryta skutečná ovce.

Všimněme si, že všechna přesvědčení v této úvaze jsou pravdivá. Do zdůvodňovacího postupu se nevkradla nepravda, přesto jsme odvodili podivný výsledek, že bychom měli skutečně vědět, že na louce je ovce. Krkolomnost odvození kritiku neoslabuje. Nevadí, že při skutečném vidění zvířete na louce nebudeme přemýšlet výše popsanou oklikou; podstatné je, že doplnění požadavku na pravdivost předpokladů nedokáže v principu gettierovským situacím zabránit.

\section{Bez rozpojení pravdy a zdůvodnění}

Jiná skupina reakcí vidí problém gettierovských příkladů v oddělení postupu, kterým získáváme zdůvodněné přesvědčení, od postupu, kterým získáváme pravdivé přesvědčení. Odkud v příkladu s ovcí bereme důvod pro klíčové přesvědčení „na louce je ovce“? Vycházíme z vidění psa. Kvůli čemu je ale toto klíčové přesvědčení pravdivé? Kvưli ovci za keřem. Zdůvodnění tedy vychází z jiné skutečnosti než pravdivost; jen pouhou náhodou se pak oba postupy setkávají v jediném přesvědčení.

Epistemologové popisují ono rozpojení různě. Podle jednoho přístupu jde v gettierovských příkladech o rozdělení oprávnění (faktu, který činí přesvědčení zdůvodněné) a „opravdění“ (faktu, který činí přesvědčení pravdivé). ${ }^{12}$ Podle jiného přístupu jde spíš o špatně zacílené poznávací schopnosti, které sice v gettierovských př́ikladech nemíríi na pravdu, přesto jí souhrou okolností dosahují. ${ }^{13}$ Pro znalost je v každém případě takové propojení důvodů

12 GOLDMAN, Alvin I. A Causal Theory of Knowing. Journal of Philosophy. 1967, 64(12), s. 357-72.

13 SOSA, Ernest. A Virtue Epistemology: Apt Belief and Reflective Knowledge. New York: Oxford University Press 2007. 
s pravdou nezbytné, a mělo by tak v definici figurovat jako čtvrtá nutná podmínka.

Jakkoli je uvedená podmínka výhodná při odlišení gettierovských příkladů od př́kladů skutečné znalosti, lze namítat, že je až př́liš silná. Vraṫme se k situaci z úvodu tohoto textu: Někdo se vás zeptá, zda je poledne. Vy odpovíte, že ano, nebot jste se před chvílí podívali na své hodinky. Ví v tomto okamžiku tazatel, že je poledne? Nepochybně ano, tak přece „znalost“ obvykle chápeme. Jeho přesvědčení je pravdivé, nebot’ je skutečně poledne. Důvodem pro jeho pravdivé přesvědčení však není fakt, že je poledne, nýbrž vaše svědectví, že je poledne. Zdroj důvodu se nekryje se zdrojem pravdivosti, oprávnění se rozchází s „opravděním“. S ohledem ke čtvrté podmínce znalosti bychom tak byli nuceni říct, že v dané situaci tazatel neví, kolik je hodin. Požadavek spojení důvodů s pravdou nás tak přivedl k důsledkům, jež nejsme ochotni přijmout.

\section{Bez vyvrácení}

Možná je pro odhalení gettierovských případů podstatné nejen to, co aktér ví, nýbrž i to, co neví. Pan Smith neví, že práci ve skutečnosti nezíská pan Jones; nevíme, že ve skutečnosti vidíme psa; nevíme, že hodiny jsou ve skutečnosti rozbité. Kdyby aktéři tyto fakty věděli, ztratila by klíčová přesvědčení svá zdůvodnění. Vždyt kdybychom věděli, že se právě díváme na psa, zcela jistě bychom naše přesvědčení, že na louce je ovce, nepovažovali za zdůvodněné.

Uvedené fakty, jež by mohly zneplatnit důvody, plní roli vyuráceni. Poslední reakce na Gettierovy př́ílady, kterou zde zmíním, chápe nepřítomnost vyvrácení jako podstatný rys všech znalostí: mít znalost znamená mít nevyvrácené zdůvodněné pravdivé přesvědčení. Zatímco tedy v příkladu s rozbitými hodinami nejde o znalost právě kvưli faktu, že hodiny nejdou, v př́kladu se svědectvím o čase nenastává nic, co by mohlo zdůvodnění anulovat, a tudíž o znalost jde. ${ }^{14}$

Toto pojetí je úspěšné při diagnóze chyb gettierovských situací, dělá však problémy u připisování znalostí. Kdy o sobě totiž můžete říct, že znáte přesný čas? Nestačí mít pravdu a důvod, potřebujete také vědět, že svět nestojí proti vám. Musíte vědět, že tam někde venku neexistuje nic, co by mohlo

14 LEHRER, Keith - PAXSON, Thomas, Jr. Knowledge: Undefeated Justified True Belief. Journal of Philosophy. 1969, 66(8), s. 225-37. 
váš důvod zrušit, žádný superpadouch podsouvající nevinným obětem přesný čas, žádný přelud, žádná skrytá oční vada. A jak se vlastně lze dostatečně ujistit, že něco neexistuje? Nevyvrácenost důvodů je rozumným požadavkem, hodnotíme-li poznávací situaci zpětně a se znalostí celého světa; v ostatních případech ale nejde o praktické kritérium.

\section{Závěr}

Gettierovy příklady nejsou kritikou naší schopnosti poznávat, nýbrž kritikou naší schopnosti poznávání popsat. Podle tradičního vymezení je znalost zdůvodněné pravdivé přesvědčení; Gettierovy příklady ilustrují, jak lze mít zdůvodněné (náhodně) pravdivé přesvědčení, a přitom nemít znalost.

Je překvapivě obtížné se s Gettierovými příklady vypořádat. K odstranění náhody můžeme požadovat zesílení vztahu důvodů k pravdivosti, ovšem za cenu ztráty mnoha znalostí. Můžeme vyloučit zdůvodňování na základě nepravdivých důvodů, vyřešíme tím však jen část gettierovských situací. Nebo můžeme při poznávání zohledňovat jen ty důvody, které nejsou vyvrácené, pak ale musíme již předem vědět téměř vše.

Gettierovy příklady zůstávají skvělou ukázkou filozofického dobrodružství. Ukazují, jak může běžný příběh otřást běžným chápáním pojmu a jak může jednoduchý př́klad upozornit na jednoduché chyby bez jednoduchých řešení.

doc. PhDr. Marek Picha, Ph.D.

Katedra filozofie, Filozofická fakulta, Masarykova univerzita

Arna Nováka 1, 60200 Brno, Česká republika

istvan@mail.muni.cz

Toto dílo Ize užít v souladu s licenčními podmínkami Creative Commons BY-NC-ND 4.0 International (https://creativecommons.org/licenses/by-nc-nd/4.0/legalcode). Uvedené se nevztahuje na díla či prvky (např. obrazovou či fotografickou dokumentaci), které jsou v díle užity na základě smluvní licence nebo výjimky či omezení př́slušných práv. 